\title{
Fragile Cities: a Critical Perspective on the Repertoire for New Urban Humanitarian Interventions
}

\author{
Manoela Miklos* \\ Tomaz Paoliello**
}

\begin{abstract}
At the end of the 1990s, researchers involved in the debate on the new wars introduced discussion about the urban dimension of contemporary conflicts into the International Relations discipline. The innovative debate about urban fragility is one of the many lines of inquiry that emerge within the framework of the relationship between cities and contemporary conflicts. This paper seeks to demonstrate that the concept of 'fragile city' offers a new and relevant analytical framework for understanding contemporary urban violence and inequality. Moreover, this same concept could also be instrumental in making fragile cities the new locus of international humanitarianism. The notion of fragile city emerges to describe new emergency situations more closely linked to urban contexts than to national dynamics, as previously described in the literature on fragile states. The concept of fragile city is a groundbreaking tool for understanding the human consequences of inequality in urban settings, but might also be used as a rhetorical vehicle for the reproduction of old dynamics and the inauguration of new intervention practices in urban areas that were previously inaccessible to humanitarian action, especially cities in Latin America.
\end{abstract}

Keywords: Fragile Cities; Fragile States; Humanitarian Aid; New and Old Wars; New Humanitarianism.

\section{Introduction}

In the midst of the debate on new wars, researchers dedicated to the topic of so-called new modalities of organised violence have introduced into International Relations (IR) new discussion on the urban dimension of contemporary conflicts (Kaldor 2013). The growing interest in the topic on the IR agenda can be seen in the growing numbers of published studies, and this suggests its increasing importance as an object of study, i.e. the urban

\footnotetext{
San Tiago Dantas Postgraduate Programme in International Relations (UNESP/UNICAMP/PUC-SP), São Paulo-SP, Brazil; manoela.miklos@gmail.com. ORCID iD 0000-0003-0222-5417.

** Pontifical Catholic University of São Paulo (PUC-SP), São Paulo-SP, Brazil; tomazpaoliello@gmail.com. ORCID iD 0000-0002-1217-4273.
} 
character of contemporary conflicts. Growth of violence in Latin American cities is one of the empirical factors that has informed the view that contemporary manifestations of organised violence have moved from what were traditional stages of conflict, or the old wars, to new contexts, principally urban ones (Koonings and Kruijt 2007).

More than $75 \%$ of the world's most violent countries are not experiencing conventional war (Muggah 2014: 4). Roughly 33\% of homicides worldwide occur in Latin America and the Caribbean, although the region accounts for only $8 \%$ of the global population. More than 130 Latin American cities with a population greater than 250000 inhabitants record what would be considered high levels of homicide - more than 25 murders for every 100000 residents per year. Some cities record homicide rates close to 175 per 100000 inhabitants a year, such as the Honduran city of San Pedro Sula (Escamilla 2015; Instituto Igarapé 2015).

The enormous impact of urban violence across diverse regions of the world, and specifically in Latin America, has captured the attention of researchers, activists, and organisations concerned with consequences of violence in environments that are not experiencing situations of conventional war. ${ }^{1}$ In this context, the concept of 'fragile city' has arisen from the need to understand the structural dynamics that lead to growing levels of violence in situations without an ongoing traditional war (Muggah and Savage 2012).

The debate over urban fragility is part of the programme developed by the discipline of IR with respect to fragile states. Such studies on urban fragility echo the literature on state fragility in that they acknowledge that the fragile condition of authority structures, as well as their complex causes and consequences, are centrally important dynamics for the definition of the expressions of security and insecurity on local, national, regional, and global levels. The present paper seeks to demonstrate that, as is the case with the concept of fragile states, the perception of urban fragility is dual. It arises as an analytical perspective aimed at studying and raising awareness about the problems of developing urban settings, especially in terms of inequality and insecurity. But the same concept might also serve as a framework and as a justification for intervention policies in cities considered fragile or in crisis.

The shifting perception of fragility from the national to the urban sphere means that humanitarian practices can be reconfigured to act in contexts far from conventional conflict, which are the traditional stages of humanitarianism (ICRC 2013). From the point of view of decision makers, principally state and non-state aid agencies from the most developed countries, such conclusions imply the revision of security doctrines and humanitarian aid (Sassen 2010; Graham 2009).

The conceptual construction of the idea of urban fragility, created in concert with humanitarian research think tanks, humanitarian aid organisations, international donors, and portions of the academic IR community, could be interpreted as what Didier Fassin (2012: 24) calls a 'new semantic configuration', a fundamental part of what the author describes as the 'humanitarian reason'. According to Fassin, this configuration of new language originates in a 'specific social world - professional, institutional, cultural - which at a given moment becomes to some extent recognised as an authorised describer of social facts and a competent provider of social responses.' These responses, as a rule, coincide 
with a set of good practices articulated in the most developed countries, moulding the cities of the global South in accordance with specific expectations, demands, values, and interests. The present paper seeks to highlight the analytical possibilities of the concept of the fragile city, but also to pinpoint the notion that 'theories and concepts are not free floating and that the coloniality of knowledge rests on the power of attributing universality to a particular experience' (Vainer 2014: 53).

The responses articulated by humanitarian organisations for the so-called fragile cities in Latin America constitute part of the wider phenomenon of the development of a 'humanitarian government'. 'Humanitarianism has become a language that inextricably links values and affects, and serves both to define and to justify discourses and practices of the government of human beings' (Fassin 2012: 2). In other words, the same theoretical framework developed to explain and criticise the sources and expressions of violence and fragility of cities has come to inform the development of new modalities of humanitarian aid and of the interventionist practice for the governing of spaces and populations.

\section{The concept of the fragile state and its critics}

The concept of the fragile city unfolds from the notion of the fragile state, ${ }^{2}$ and it is from this research concern that authors have sought to establish the nexus between state fragility and urban environments. Therefore, the notion of what constitutes urban fragility and the development of the concept of fragile city should be understood from the starting point of the development of the idea of the fragile state.

Sorensen (1999) defines the fragile state as a territory whose institutions, as well as the economic and political processes that emanate from them, are weakened.

A range of concepts have emerged to describe states that do not live up to common understandings of how states should work, ranging from collapsed, failed and failing states, to fragile, crisis, rogue and poorly performing states, difficult partnerships, and low-income countries under stress. These concepts have often been used indiscriminately. While the terms 'collapsed' and 'failed states' are usually reserved for cases where central state institutions and authority have ceased to function, 'fragile states' is increasingly being recognized in the donor community at least - as a common descriptor of states that represent persistent challenges for the donor community by not living up to Weberian expectations and by foreshadowing the risk of collapse in the future (Stepputat and Engberg-Pedersen 2008: 21).

Oliver Nay (2012) contends that literature aimed at critiquing the conception of fragile states first developed in the mid 2010s, in reaction to the increasingly widespread use of the term. According to the author, this literature is organised around five 'families' of critics grouped into common central arguments. Of these five groups, there are three particularly interesting arguments that can be transposed to the literature on urban fragility. ${ }^{3}$ The first argument, classified by the author as 'portmanteau concepts' refers to the polysemic 
aspect of the concept of fragile state. According to Nay (2012: 7), this critique is derived from the authors' inability to agree on a firm definition of the concept.

There are many authors and institutions that adhere to the use of the term 'fragile state.' The diffusion of the use of this concept by national and international aid and development organisations is notable. For the Organisation for Economic Cooperation and Development (OECD), a fragile state is 'unable to meet its population's expectations or manage changes in expectations and capacity through the political process' (OECD 2008: 76). On the other hand, the Department for International Development (DFID), the principal international aid agency of the British government, considers fragile states to be 'those where the government cannot or will not deliver core functions to the majority of its people, including the poor' (DFID 2005: 7). Putzel's (2010) critique applies to the two definitions when he states that there is no clear distinction between what is understood as 'fragility' and what would be traditionally understood as under-development. In other words, the definitions of fragility could apply to all poor countries. It is worth noting that the objective of utilising the term 'fragile' is to 'mak[e] the concept operational for development policy, according to the aid organisations themselves (Stewart and Brown 2009: $6)$.

An attempt to define fragility would be of little use. Notwithstanding this, it is possible to point to some of the principal characteristics of fragility, which will be taken up again later. The notion of fragility of the state is articulated as a supposed weakening of the political institutions in a certain territory. This fragility can be identified through an analysis of these same political institutions, especially the incapacity of the police and the armed forces to provide public security. In this sense, civil war and high crime rates could both be identified as evidence of state fragility. Fragility could also be highlighted by the presence of violent non-state actors, such as guerrillas, gangs, terrorist groups, and transnational organised crime groups in the territory of these so-called fragile states. The weakness of state actors or the strength of non-state actors both serve as indicators that the state has failed to guarantee the institutional aspects of a 'Weberian state' (Nay 2012: 9).

State fragility may also be measured through its consequences. From a humanitarian perspective, the evidence of the incapacity of public institutions includes extreme poverty, health risks, and the abuse of human rights (Patrick 2011). The Crisis States Research Centre (CSRC), affiliated with the department of International Development at the London School of Economics (LSE), and financed by the DFID, defines as fragile those states significantly susceptible to crises in one or more of their subsystems, a territory vulnerable to what these researchers called 'internal and external shocks', as well as domestic and international conflicts (CSRC 2006: 1). The definition developed and utilised by the CSRC confirms the perception that the notion of fragility is associated with the notion of crisis, which has central importance in the definition of situations of humanitarian action and in the allocation of international aid. But both the notion of crisis and that of fragility can change their meanings depending on their context.

The flexibility of the concept of state fragility, associated with persistent use of the term by international aid organisations, is coherent with the second critique classified by 
Nay (2012: 7), that is, 'political labelling.' This argument reveals that the use of the lexicon of fragility works selectively, articulated mainly by the interests of the Western powers.

[T] he labelling of states as failed has less to do with a particular state's functioning and more to do with its ability and willingness to be a relevant partner for Western countries in their efforts to guarantee their own security, access to resources, and support for their security interests (Solomon 2013: 233).

Ultimately, the judgment of fragility could serve as a legitimising discourse for international humanitarian interventions operating through a governance system comprised of Western powers. These mechanisms of governance do not consist only of military operations, but also unite international organisations, Western bilateral agencies, and national authorities in countries undergoing reconstruction after conflict or disaster (Nay 2012: 7). This critique is directly associated to Fassin's (2012: 2) perception that humanitarianism is a new form of 'government of human beings'. In this case, these forms of government would be exported from Western countries to territories of the global South through complex governance mechanisms.

Finally, the third argument that is critical of the notion of the fragile state is that which Nay (2012: 9) classifies as 'Western centrism'. Authors aligned with this critique highlight the fact that states are considered solid or successful when they are in accordance with the Western standard. The literature on fragile states has, nevertheless, a general predisposition towards ignoring the great variety of historical and cultural situations that have resulted in heterogeneous political and institutional arrangements. It means that even 'progressive' authors concerned with poverty, violence, and other manifestations of human suffering could also be reproducing Western values and interests. The discourse on fragile states has the potential to reactivate a teleological perspective that presupposes that all states should advance towards a similar end point, which mainly corresponds to the dominant model of the Western state (Call 2008: 1499).

In addition to highlighting the particular characteristics of states of the global South as dysfunctionalities, the notion of the fragile state can also obscure the responsibility of forces originating from the Western states. These dynamics could be related to the colonial past or to practices that are configured as new forms of colonialism, such as the behaviour of international financial institutions and development agencies in the formation and maintenance of fragility. Therefore, the discourse of fragility of the state corresponds with and contributes to the inequalities of international power.

\section{The fragile city}

Amid the debate on the fragility of states, studies begin to reflect on the importance of cities and the urban environment in the context of fragile states. To identify the gaps in the debate on the so-called fragile, failed, and collapsing states (FFCSs) authors such as Pureza have suggested that there is an absence of deep knowledge of local realities (Pureza 2005), in line with the view that the literature privileges a uniformity of the perception of fragil- 
ity, constantly accompanied by 'one-size solutions' (Nay 2012). Accordingly, an advance in the understanding of local institutions, as well as the forms of organisation and the causes of the conflicts and of how such processes manifest at the local level, would be necessary. The authors concerned with the fragility of urban centres and their nexus with the fragility of the state seek to overcome such a lack of knowledge and fill in such gaps. ${ }^{4}$

The emergence of the debate on the fragility of urban settings responds to two synchronous tendencies in field of IR. Rao (2006) identifies the overlap of an 'urban turn', a growing interest in studies on the city, with a 'Southern turn', a growing interest in the historic and social formation of non-Western societies. This turn responds to an ambiguous trend, since it could be represented by recognition of the value of analyses produced from the global South, but reveals itself mainly in the interests of Western authors in studying specific dynamics of Southern cities (Rao 2006). This means that the debate on fragile cities echoes some of the same limitations and dangers identified in the idea of fragile state.

The volume entitled 'Fractured cities: social exclusion, urban violence and contested spaces in Latin America' (organised by Koonings and Kruijt (2007), researchers from the University of Utrecht), represents a landmark in the study of fragility in the urban dimension in Latin America, and is aligned with the set of works informed by the co-occurrence of the urban turn and the Southern turn. Koonings and Kruijt identify two general structural tendencies spanning through various major urban centres in the region that are constitutive of Latin American cities. The point of departure is what the authors define as a 'syndrome of poverty, inequality and urban social exclusion' (Koonings and Kruijt 2007: 2 ). This is a defining characteristic of such fractured cities, profoundly unequal and exclusionary, especially for its poorest citizens. These dynamics have been aggravated recently, serving as the backdrop to the high levels of violence demonstrated in the cases studied.

The second concern in Koonings and Kruijt's text is the perception of withdrawal or failure of the state locally, in certain regions of the city. This supposed state failure is demonstrated through its incapacity to implement public security functions. The expansion of the so-called 'governance gaps' and the absence of rule of law are recognised as important elements in the relation between exclusion, insecurity, and urban violence. The authors' perspective on the violence in Latin American cities echoes many of the same formulations that describe the territories of the so-called fragile states. The two trends in Latin American cities, related to humanitarian crises and to the absence of state authority, could correspond to what was described earlier as the dimensions of state's fragility. The unequivocal manifestation of the transposition of concepts from the national to the urban level is made explicit by the use of the term 'war' to describe urban violence in Latin American cities (Koonings and Kruijt 2007: 17). According to these authors, the violent cities studied can be described as being in situations of 'mini wars,' defined by violent disputes in urban territories. ${ }^{5}$

Koonings and Kruijt's perspective (2007), which hierarchically places human suffering above state failure, coincides with what Fassin defines as one of the structural points of the humanitarian reason. Government practices, traditionally associated with repression, have shifted towards compassion. The result of this shift is the privileging of exclusion as 
the principal problem of social administration. It is this same exclusion that is the common point of the great majority of analyses concerned with urban fragility.

In the early 1990s two new terms emerged that anchored public action solidly in the compassionate register: 'exclusion' and, above all, 'suffering.' In both cases the state administration and the social sciences played a pivotal role and came together in legitimizing these new categories politically and intellectually (Fassin 2012:31).

The emergence of the term fragile city to describe a new space of humanitarian action is pivotal to understand the link between political interest and intellectual production. As will be shown, the concept carries a double bias. It has a descriptive importance, but also carries the potential of legitimising new interventions.

In 2006, the LSE created the research programme 'Cities and Fragile States' (Beall, Goodfellow and Rodgers 2011). The program made efforts to monitor the nexus between cities and the fragility of authority structures. Both CSRC and 'Cities and Fragile States' are linked to DFID, the organ of the British government responsible for international aid programs. The perception of the nexus between city and state fragility corresponds to a specific interest: to produce knowledge for certain actors to operate in areas of state fragility. Such operations have, ultimately, the objective of implementing development policies and the strengthening of state institutions, particularly for urban contexts (Beall, Goodfellow and Rodgers 2011: 1). Moreover, the programme is part of a wider cooperative effort between LSE and DFID to formulate concepts, categories, and hypotheses to support the actions of humanitarian interventions developed and sponsored by the British government (Putzel and John 2012). The formation of the programme is symptomatic of the assemblage of actors interested in formulating knowledge for acting in cities. International donors, think tanks, national and international aid agencies, and academia come together to develop new concepts and practices.

In 2012, in the paper 'Urban Violence and Humanitarian Action: Engaging the Fragile City', researchers Muggah and Savage formulated the concept of the fragile city for the first time in an academic article. ${ }^{6}$ The intention to transfer knowledge from the concept of fragile state to city cases is clear. The authors describe the first definition of the term in the following lines:

The emergence of fragile cities as a category suggests that the referent of international attention is correspondingly expanding. That is, fragility is no longer confined exclusively to the domain of states but is rather extending to their capitals and outlying metropolitan regions as well. The international security and development optics are scaling outwards to account for chronically violent and ungovernable cities and neighborhoods in which public authorities and civic actors have lost control, are unable or unwilling to deliver basic public services, and cannot fulfill their essential function of providing 
security, welfare and legitimate representation (Muggah and Savage 2012: 1).

Much of what makes an urban centre a fragile city is echoed in the definitions that anchor the debate over fragile states. It is noteworthy that one of central points of the parallelism between urban fragility and state fragility revolves around the idea of an erosion of authority. According to Koonings and Kruijt (2007: 17):

One of the key aspects of contemporary urban poverty and social exclusion is the failure of the state to guarantee citizens' security and the rule of law vis-à-vis what they euphemistically call the underprivileged. This failure is reflected in the incapacity to protect citizens from everyday and organized violence.

Raleigh (2015: 1) reproduces the same perception, when she identifies that "Fragile cities" are emerging as a new category of societal disorder, wherein frail and failed conditions normally associated with severely underdeveloped states are applied to urban centers.' Therefore, the fragile city could be identified as a source of local, national, regional, and global insecurity. Consequently, it could be an entity that arouses the interest of the international community. The logical consequence of such a process is that the city consolidates itself as a new frontier in the measures of international intervention: 'Cities are thus emerging center-stage in debates on counter-insurgency, stabilisation, and crime prevention' (Muggah 2013).

Finally, it is worth highlighting the growing relevance of the term 'fragile city' for mainstream IR. 'Fixing Fragile Cities' (Muggah 2015a) was published in the North American journal Foreign Affairs, one of the most important academic publications in the field of IR. In the same year, the paper 'Urban Violence Patterns Across African States' (Raleigh 2015) was published in the important scientific periodical International Studies Review, a journal affiliated with the International Studies Association. The publication of these two articles in important journals, whose content generally reflects what is considered to be mainstream IR, is evidence of the growing academic relevance of the topic. The growing acceptance of the concept and the ideas upon which it relies also shows its increasing capacity to legitimise power relations.

\section{Fragile cities as a new terrain for humanitarianism}

In an article entitled 'Feral Cities', published in 2003, Richard Norton showed astonishment at the absence of policies for humanitarian aid destined to combat urban fragility. For the author, cities in situations of crisis of authority and security represent a growing threat to the international community. Consequently, such cities should awaken a growing interest among government, military, non-government, and intergovernmental organisations interested in mitigating the vulnerabilities found in these territories, aimed at reducing their potential as international threats (Norton 2003). Since 2003, the panorama of 
actors engaged with the topic of fragile cities has transformed, and the author's predictions seem to have been proven right.

As described earlier, researchers who produce analyses on urban fragility present, from the start, a dual-natured concern. In the first place, there is an academic concern. The investigation undertaken so far aims at understanding urban fragility through the formulation of hypotheses for its occurrence and the identification and denouncing of their consequences. The concept of the fragile city helps to reveal how poverty, inequality and violence have deep and perverse human consequences in developing urban settings. But some of the same authors also demonstrate a second order of concerns: to investigate the dynamics that permeate urban fragility in search of remedies for the causes and symptoms of fragility. This would arise as an issue particularly for the organisations involved with humanitarian action. In accordance with this vision, the fragile city could be seen as a problem to be solved. The concept of the fragile city could be understood as having a double purpose: to contribute to the understanding of the phenomenon of the fragility of urban centres and to inform practices developed by humanitarian aid agencies.

In 2007, Kruijt and Koonings activated 'humanitarian reason' as a justification for the relevance of the study of violence in large Latin American cities. Specifically, the call to action from the international community is anchored in the principle of human security.

We suggest here that human security should mean the freedom of individuals and communities form threats posed by conflict and violence to their physical, social and cultural integrity or survival. [...] That is to say, individuals and communities are, ideally, citizens because they are right-bearers to the extent that they are incorporated into nation-states and (increasingly but tentatively) into an international community which abide by the principles of democracy, rule of law and humanitarian standards (Koonings and Kruijt 2007: 13).

In a paper entitled 'It's time for humanitarian agencies to work in fragile cities', Muggah (2015b) points to the growing production of knowledge on humanitarian action in fragile cities.

The causes and consequences of city fragility are getting attention with some humanitarian agencies starting to work in, and on, urban violence. For example, relief agencies across the US have mobilized assistance for the tens of thousands of Central American children crossing the border from Mexico. For more than half a decade, the International Committee of the Red Cross (ICRC) has tested new programs to address so-called 'other situations of violence' in cities such as Medellin, Rio de Janeiro and Tegucigalpa. Médecins Sans Frontières has also initiated violence prevention activities in inner city neighborhoods across the Americas. Even so, not all aid agencies are convinced (Muggah 2015b: 1). 
The formulations present in many of the texts can be characterised as self-fulfilling prophecies. Studying a city characterised as fragile has the potential of attracting the attention of international actors through the activation of what Fassin (2012) calls 'humanitarian reason'.

[W] ords uttered in the public arena may be both constative and performative at the same time, being presented as a pure observation of facts while contributing to bringing these facts into existence: to speak of insecurity as a mere description of reality is to participate in bringing the feeling of insecurity into being (Fassin 2012: 33).

On mentioning fragile cities, the authors reproduce one of the dilemmas that permeate the contemporary debate over fragile states: the analytical categories produced to explain and denounce fragility could also lend themselves to informing humanitarian aid practice in contexts diagnosed as fragile.

A series of actors engaged in humanitarian aid actions have reported a growing interest in so-called 'other situations of violence' (Muggah 2013: 1). ${ }^{7}$ The contexts in which agencies dedicated to humanitarian aid have traditionally acted were stages of old or new wars, as well as locations where natural disasters occurred. Urban centres inserted into national contexts of formal peace and diagnosed as fragile constitute the new terrain of action for such actors (Palus 2013).

There are many indications that the literature developed through studies on urban fragility has become a framework informing new practices of humanitarian aid. International actors have increasingly taken ownership of such a literature. Muggah (2014) recognises that decision makers, fearful that the diagnosis of fragility could be used to justify and legitimate interventions, frequently react by questioning the label of 'fragile city'.

Mayors and governors presiding over these cities are often quick to call attention to state and municipal deficits, in some cases invoking fragility as a means of unlocking resources or shaming authorities higher up the food chain. Not surprisingly, there are concerns in some quarters - especially foreign ministries of many of these same countries - that this logic can potentially give rise to new forms of (international and domestic) interventionism. Thus, diplomats from Brazil, China, Mexico, Pakistan, Russia and the United States fiercely contest the label, concerned as they are with everything from resisting encroachments on their sovereignty to maintaining investment flows and tourist revenue (Muggah 2014: 4).

This perception coincides with what the critics of the notion of the fragile state call 'political labelling. The use of the lexicon of urban fragility could lend itself to the same selectivity, articulated with the practices, values, and interests of the West, even if it is not the authors' original intention. Indeed, important humanitarian organisations, such as the International Committee of the Red Cross (ICRC) and Médecins Sans Frontières (MSF), have engaged in new practices in fragile cities. The position of humanitarian organisations 
is that the fragility of cities puts the resident population, as well as national, regional, and global order, at risk. Therefore, fragile cities could constitute a new stage for humanitarian action (Muggah and Savage 2012: 1).

In 2014, Reid-Henry and Sending published 'The "Humanitarization" of Urban Violence, in which they discuss the action of humanitarian agencies in contexts of urban fragility. For the authors, urban violence was a problem traditionally handled in the domestic realm by the local and national administration. However, they recognise that the concern with urban violence has come to be, with increasing visibility, a topic appearing on the agenda of the international community. Their paper debates the influence of the international community in the development of public policies to mitigate fragility, specifically high levels of violence. With respect to the responses that local governments give to the challenges that arise from the condition of fragility, the authors state that: 'What is of interest (though it goes somewhat under-remarked) is that many of these are in fact internationally driven responses that work to contain the problem within the places where it is found' (Reid-Henry and Sending 2014: 429).

According to Reid-Henry and Sending (2014), the performance of the organisations dedicated to humanitarian aid in fragile cities corresponds to the adoption of new guiding principles of humanitarianism. The origins of the violence have not traditionally been an object of reflection on the part of humanitarian aid agencies. The objectives of such institutions did not include, until recently, acting to eliminate the causes of violence, but only for the relief of their consequences. However, operating in fragile cities has brought about substantial changes in the practices of humanitarian organisations during recent years. In the words of Reid-Henry and Sending (2014: 431):

$[\mathrm{H}]$ umanitarian organizations have over recent years, [...] expanded their operations more generally, beyond simply offering relief. Especially since the end of the Cold War, IHOs have increasingly begun to act on the root causes of suffering rather than its amelioration, and it is in this context that the challenge of the city has been raised.

It is possible to notice a fundamental change in relation to the way violence has been treated since the start of the debate on urban fragility. For Koonings and Kruijt (2007), urban violence was a structural aspect of the unequal and socially exclusionary cities in Latin America. For Reid-Henry and Sending (2014), violence comes to be seen as a problem to be solved. In the discourses built around the humanitarian reason, urban violence (an indication of the incapacity of the local state to guarantee the security of its citizens), has become a problem in itself instead of a consequence of poverty and inequality.

We will argue below that the institutions dedicated to humanitarian aid incorporate the literature produced on urban fragility and transform their activities significantly. Such transformations correspond to two new distinct shifts: 1) a spatial shift, which translates into operating in new areas that are not localised in war zones or areas of natural disasters, the fragile cities; and 2) a procedural shift, which translates into the widening of the humanitarian scope of action in such new locations. 


\section{Urban fragility: new perspectives informing new practices}

With respect to the spatial shift just mentioned, it is possible to state that fragile cities are a new terrain for humanitarianism. Below, we present evidence that corroborates such a statement. This effort should not be understood as an exhaustive list, but as a selection of initiatives that indicate that institutions dedicated to humanitarian aid have been acting with growing assiduousness in urban centres diagnosed as fragile - especially cities located in states which are not involved in a situation of conflict or post-conflict, particularly in Latin America.

One more caveat is necessary: in the past, organisations dedicated to humanitarian aid developed actions in urban terrain. In particular, they acted in urban contexts that could be considered fragile amid peaceful situations - or beyond war zones. This fact is not in question. The hypothesis defended here is that there is an urban bias in contemporary humanitarianism, or in the new humanitarianism, ${ }^{8}$ and that this bias is largely new since it is the result of a conscious move systematically reiterated by the main institutions that provide humanitarian aid. Finally, we will see that the option of working in fragile cities arises from the appropriation, on the part of the actors connected to humanitarianism, of the literature produced on fragility mentioned above.

Reid-Henry and Sending (2014) declare that there is an important milestone of what we can call the urban awakening of humanitarianism, as the fragile city becomes a privileged terrain for humanitarian aid practices. Such a milestone is the event 'Meeting humanitarian challenges in urban areas', organised by the Inter-Agency Standard Committee (IASC), in 2010. The IASC is a committee that brings together the organisations in the United Nations (UN) system dedicated to humanitarian aid and independent humanitarian organisations, such as the ICRC.

The objective of the meeting was to outline a plan to reform humanitarian agencies' procedures so that they could operate in a more efficient manner in cities. The final report that summarised the debates held at the meeting in 2010 presents a plan of work to be developed by the participating institutions (IASC 2010). This plan is: 1) develop operational strategies that guarantee partnership with interested parties and reinforce the impact and the efficacy of humanitarian aid in urban areas; 2) strengthen technical capacity for emergency response in urban-based challenges; 3 ) develop or adapt humanitarian approaches and tools for urban areas; 4) promote the protection of vulnerable urban populations against violence and exploitation; 5) restore livelihoods and economic opportunities as a priority; 6) prepare humanitarian assistance policies for more effective emergency responses that save more lives in urban areas. The IASC report highlights the substantive transformations that acting in urban locations will demand of the humanitarian organisations (IASC 2010).

Indeed, as stated by Reid-Henry and Sending (2014), in the period that preceded the IASC event, a growing number of organisations involved in humanitarian aid had started to show an interest in operating in fragile cities. In 2010, the International Review of the Red Cross published an entire volume dedicated to humanitarianism in the urban setting, entitled 'Humanitarian debate: Law, policy, action - Urban violence'. The volume opens 
with an interview with Dennis Rodgers, researcher from the Cities and Fragile States programme. The interview is indicative of how the literature on urban fragility informs new humanitarian aid practices. It is worth noting that the term 'fragile city' is first mentioned in this report. The term is cited in the chapter 'Humanitarian challenges of urbanisation', authored by Raimond Duijsens, a Red Cross official in the Netherlands. The term is mentioned only once with no theoretical ambition: 'The fragility of the country is reproduced on a local scale, giving rise to fragile cities' (Duijsens 2010: 361).

The concern over urban fragility in Duijsens' (2010) text demonstrates that the relevance of the theme has repercussions for other large donors besides the United Kingdom. Urgence, Réhabilitation, Développment (URD), a French institute that defines itself as an organisation dedicated to the development of policy for humanitarian sectors, produced an extensive report in 2011 entitled 'Humanitarian aid in urban settings: Current practice, future challenges', authored by a group led by Grünewald (2011). In this report, the researchers define fragile cities as opportunities for humanitarian organisations to act - state agencies and organised civil society.

In 2013, the ICRC produced the document 'Urban Violence: What Role for Traditional Humanitarianism?' It offers an example of the efforts to rethink the practices of humanitarian aid as they adapt to the contexts of urban fragility. It can be thought of as another indication of the favourable disposition of humanitarian actors in adapting the traditional ways of providing humanitarian aid in situations of conflict and post-conflict to the so-called 'other situations of violence' that can be seen in fragile cities. 'The document is the result of an event of the same name realised in 2013. It was organised by the ICRC and the All-Party Parliamentary Group on Conflict Issues (APPGCI), a British parliament initiative, whose objective is to promote dialogue between the English government and organised civil society. The event brought together the ICRC, British public administrators, and a series of researchers concerned with the theme of urban fragility. According to the ICRC, humanitarianism is undergoing a new revolution: the necessity of adapting its grammar to contexts of urban fragility in areas of formal peace - fragile cities (ICRC 2013).

The document produced by the ICRC in 2013 supplies some indications of the necessity of justifying interventionist policies in contexts in which there is no armed conflict as traditionally understood:

It is not only humanitarians that are being forced to adapt to an 'urban century' however. The military doctrine of countries such as the United States show [sic] how the 'urban battle space' is predicted to become one of the dominant modes and sites of 21 st century warfare. Humanitarian organisations have worked for decades in cities caught in the midst of armed conflicts [...] however they have also been relatively slow to respond to the specific characteristics and dynamics of violence generated by an urban environment. [...] In addition the humanitarian community has shown caution in developing programmes in cities where there is not an armed conflict 
but still violence which may be predominantly criminal in nature, because these situations sit outside of the purview of IHL (ICRC 2013: 2).

The report mentions that, in 2012, nine times as many people died as victims of urban violence as those who died from violence in wars (ICRC 2013). In this sense, it is possible to trace a parallel between the perception of the agencies and the view of the researchers mentioned previously. The diagnoses regarding the situation of urban fragility and its impacts are analogous. Although not explicitly mentioned, the document evidently refers to the violent situations in the cities of Latin America.

The report produced by the ICRC corresponds to the actions of the Red Cross in the field. The city of Rio de Janeiro opened a Red Cross pilot programme in 2009 to operate in the urban zones considered fragile - the programme Opening Humanitarian Spaces (Abrindo Espaços Humanitários). Its objective is to offer humanitarian aid to vulnerable communities, especially to residents of the favelas.

The ICRC has launched a pilot project in Rio de Janeiro. The aim of the project, which has been planned over five years, is to protect the most vulnerable people affected by violence, namely the communities who live in seven favelas containing over 600,000 inhabitants, with a particular focus on youth and the prison population - which is an essential component of the armed violence dynamic. The ICRC operates in the poorest sectors of these favelas, which are not easily accessed by state services and where the inhabitants are in precarious and sometimes illegal situations (Harrof-Tavel 2012: 345).

Regarding the Red Cross pilot project in Rio de Janeiro, João Pontes Nogueira (2014) states that, in accordance with the premises of the project, the population is treated in a fashion analogous to how the agency treats populations in a war situation - although the Rio case cannot be defined as such, neither de jure nor de facto. To treat the population in this manner, the ICRC would have to justify its right to a humanitarian initiative (2014: 15).

In an interview for the Observatório de Favelas (2009), the then representative of the ICRC for the countries of the Southern Cone, Michel Minning, affirmed that there was no contradiction for the Red Cross in operating in vulnerable communities in fragile cities which are not experiencing a war situation. Minning states that the basis for humanitarian interventions 'is respect for life and for dignity', which means that any territory would be eligible for international action. In Rio de Janeiro, in Minning's words, there is no war, legally speaking. However, there are 'serious elements that cause humanitarian situations, conflict elements.' Among these elements is the existence of groups dedicated to organised violence, such as the commandos and the militias. Minning, in the same interview, stated: 'the methodology to get to the communities is the same that we use in armed conflicts: through notification and the establishment of a dialogue with local authorities, in this case, the commandos themselves' (Suzin 2009: 1). 
MSF has also launched a pilot programme to aid in mitigating the high levels of violence in fragile cities. The programme is based in the city of Tegucigalpa, in Honduras, and consists of sending mobile medical units into the neighbourhoods most affected by drug trade violence. In these locations, according to the organisation, medical services are practically non-existent (IRIN 2013). MSF's justification for the operation in Tegucigalpa has parallels with the hypothesis posited by researchers interested in urban fragility. As the organisation puts it:

At first glance, the streets of Tegucigalpa seem calm. However, Honduras's homicide rate is the highest in the world. This frightening statistic is largely due to drug trafficking. Most of the cocaine consumed in the United States is transported through this region. Gangs involved in the drug trade extort businesses, terrorize the population, and engage in vicious turf wars. MSF is providing medical care to the victims of this 'epidemic of violence', as MSF's Javier Rio Navarro describes it (MSF 2012: 1).

It should be noted that in the quote above the concern with respect to violence in Tegucigalpa is directly related to its consequences for the United States. In other words, it also reveals the relation between humanitarian aid and the containment of the threats of the global South in relation to central countries.

The Active Learning Network for Accountability and Performance in Humanitarian Action (ALNAP), published a report in 2012 entitled 'Responding to urban disasters: Learning from previous relief and recovery operations'. In this report, ALNAP analysed the operation of humanitarian aid agencies in cities affected by natural disasters. Two years later, in 2014, the network continued activities centred on humanitarian organisations' operation in urban territory, now concerning themselves explicitly with the presence of such agencies in fragile cities. The report, authored by Elena Lucchi and entitled 'Humanitarian interventions in situations of urban violence', sought to systematise the lessons learned from the projects developed by the organisations that provide humanitarian aid in cities considered to be fragile. The report reveals the impact of studies concerned with urban fragility that informs humanitarian institutions' practices in urban territories considered fragile.

ALNAP also maintains The Urban Humanitarian Response Portal, a web portal developed in partnership with UN-Habitat, whose objective is to share knowledge on humanitarian crises in urban contexts. The website is a repository of reports on policies, tools and methodologies considered relevant for humanitarian organisations to respond efficiently to humanitarian crises in cities. It is an initiative whose ultimate objective is to produce and reproduce knowledge to inform the action of state or organised civil society humanitarian aid agencies in fragile cities, or in the language of the ICRC, in 'other situations of violence. In the reports, the cases of Rio de Janeiro and Tegucigalpa, among others, are employed with the aim of creating laboratories for the development of good practices. 
Finally, it is necessary to highlight the fact that the most important international donors - state co-operation agencies or philanthropic foundations - demonstrate a growing interest in intervening in fragile cities. As we have seen, the Cities and Fragile States programme was sponsored by DFID, the main humanitarian aid organ of the British government. The largest financial backer of ALNAP is the US Agency for International Development (USAID), the US government's main civilian aid agency. Standing out as noteworthy among the backers who contribute to ALNAP are the DFID, the Agencia Española de Cooperación Internacional para el Desarrollo (AECID, the Spanish Agency for International Development Cooperation), the Australian Aid Program (AusAid), the Swedish International Development Cooperation Agency (SIDA), and the Canadian International Development Agency (CIDA) (ALNAP 2014). Moreover, the director of the Humanitarian Policy and Global Engagement division of USAID and one of the directors of DFID both presently compose the board of directors of ALNAP.

De Boer (2015) cites other examples of international donors who invest in actions to mitigate the effects of fragility of urban centres:

An increasing number of initiatives are also investing in and testing smart and scalable solutions that promote resilience at the city level. These include the Rockefeller Foundation's 100 Resilient Cities Initiative, the DFID and IDRC-funded Safe and Inclusive Cities initiative, the C40 Cities Climate Leadership Group, the Ford Foundation's Just Cities Initiative, the Siemens SENSable City Lab, and IBM's Smarter Cities program. [...] Through these initiatives, we are also witnessing researchers team up with policy makers and private sector actors in a multi-disciplinary way to explore solutions that will make cities more resilient to disaster and violence (De Boer 2015: 1).

The funding for the development of a conceptual framework on fragile cities is part of a co-constitution complex between the demand for this knowledge and the knowledge itself. The growth in awareness among analysts and researchers of the contexts of urban violence has transformed what the perception of threats is for large donors. On the other hand, these organisations will increase the resources channelled to the production of knowledge for action in the context of urban fragility, feeding a cycle of apparent consensus on the question of what Fassin (2012) defines as the 'new semantic configuration' that supports humanitarian reason.

The urban option for humanitarianism manifests itself, therefore, around a complex system that involves academia, where the conceptual framework relative to fragile cities is developed; humanitarian aid think tanks, responsible for transposing this framework into humanitarian organisation action; the large humanitarian aid international organisations that transform their framework of action in line with the knowledge produced; and the large international donors that sponsor these initiatives and have their aid guidelines informed by them in tandem with these organisations. ${ }^{10}$ This dynamic is built around the 
concept of a fragile city and the equalisation of these contexts with situations of war. The intricate web of actors, producers of knowledge, and of humanitarian action face the challenge of developing a new scope of operations for which there are no clear consolidated judicial guidelines. The notion of the fragile city bestows legitimacy on the operations in the absence of such legal frameworks.

The question that this raises for humanitarians is how they can best learn to deal with both local security services and local gangs on the one hand, and competing discursive constructs on the other. How, for example, should they deal with the wider political implications of large-scale violence that is not covered by International Humanitarian Law? (Reid-Henry and Sending 2014: 438).

The great variety of authors and actors presented here demonstrates that the same theoretical framework developed to understand the expressions of violence and of the fragility of cities is also capable of informing the development of new modalities of humanitarian aid and interventionist practices.

\section{Conclusion}

The new urban humanitarian bias has uncertain implications that demand careful analyses. In identifying the fragile city as a stage for humanitarian crises and regional and global threats, the humanitarian aid institutions have come to act in what can be understood as a normative vacuum. The international community sees itself immersed in analogous dilemmas to those confronted when a state is diagnosed as fragile and the decision is made to intervene in such a territory. Delicate questions related to legality and legitimacy spring from such new practices of humanitarian aid. The increase in the number of humanitarian operations in urban territories diagnosed as fragile cities demands attention from researchers involved with the fragile city research agenda, as well as the field of IR.

The cases of the Red Cross in Rio de Janeiro and MSF in Tegucigalpa illustrate how recent humanitarian experiences in urban environments have been influenced and justified by the logic of urban fragility. Furthermore, the repercussion of these cases on reports produced by humanitarian think tanks shows that humanitarian action in fragile cities can also serve as a laboratory for further developing humanitarian practices.

The formulation of the 'fragile city' concept carries a double bias. If, on the one hand, the knowledge constructed around this innovative category reveals the dynamics of violence and inequality in peripheral urban settings, then on the other hand it could also be used as part of a discursive construct to support new interventions (Reid-Henry and Sending 2014: 438). Humanitarian interventions in urban environments replicate many of the same dilemmas encountered in interventions under the logic of the fragile state. The vague definition of the criteria that define the fragile city can contribute to its operationalisation by political agendas. The criteria for defining fragility are also often related to the values and standards associated with Western cities and tend to overlook the great 
variety of historical and cultural situations that have resulted in heterogeneous political and institutional arrangements. This ambiguity is even more worrisome if we consider that, following Vainer (2014: 51), the diffusion of discourses and practices formulated as mechanisms of power is not the privilege of conservative groups. This means that the concepts and practices created in the global centres of power could still be reproduced in works which both denounce social problems and raise awareness to overcome them in the cities of the global South.

The same emancipatory discourses that articulate the notions of stabilisation and reconstruction run the risk of conferring legitimacy to practices which aim at building an order that attends to the interests of the great powers and international institutions (Duffield 2001). Ultimately, it is necessary to be concerned with the urban bias of humanitarianism if it constitutes a power resource and if the work of humanitarian agencies in fragile cities becomes a tool for the construction or maintenance of hegemonies. Using the formulation of Roy (2016), the fragile city should not become one more theoretical manifestation that proclaims the history of Europe as a universal history, becoming a vehicle for the diffusion of values and interests. The notion of urban fragility is articulated with humanitarian reason, and can function as a vessel for new practices of government in 'peripheral' regions. It will be up to future analysts to distinguish between the analytical gains of a groundbreaking concept that relates emergence of new forms of violence in urban context with poverty and social inequality, and the concept's use as a legitimising discourse for new interventions.

\section{Notes}

1 The literature on the so-called 'new wars' draws a distinction between wars of a new kind and 'old wars', or conventional conflicts. This type of conflict would be characteristic of a historical period that had the states as the main actors in international conflicts. The phenomenon characterised as globalisation imposed a transformation in the dynamics of war, characterised, among other factors, by the emergence of new non-state violent actors. According to Kaldor (2006:17), 'War was recognizably the same phenomenon: a construction of the centralized, rationalized, hierarchically ordered, territorialized modern state. The centralized, territorialized modern state gives way to new types of polity emerging out of new global processes, so war, as we presently conceive it, is becoming an anachronism.'

2 Although constantly used synonymously, the term 'fragile state' is often presented by authors as an 'evolution' of the concept of failed state, since it responds to deficiencies present in the original definition. One such deficiency concerns the fact that the notion of state failure is efficient only to describe limited situations. Failed states would be states 'that can no longer reproduce the conditions for their own existence' (CSRC 2006). The subjacent logic to state failure is binary, as it implicitly describes two types of states, strong and failed.

Authors who share this critical perception understand that the notion of fragility would be able to describe a wider range of phenomena, a continuum of various forms of fragility. The idea of state failure overemphasises the connection between this category and problems related to security, especially conflict and war. The notion of state failure, according to such literature, would not be able to adequately reflect the myriad of explanations of a state's deficiency in exercising its functions. 'Both theory and policy on state fragility are poised to move beyond post-Cold War "first generation" perspectives which tended to equate failure with armed conflict and institutional breakdown resulting from war and intrastate struggle. These "first generation" approaches focused on mono-causal explanations of state performance by giving credence to claims that failure and collapse were a function of political discord' (Carment, Prest and Samy 2007: 13). 
The adherence of authors to the concept of state fragility, to the detriment of the use of the term 'failed state', reflects the search for a theoretical framework capable of adequately interpreting deficiencies in the state's exercise of its functions. In this sense, the difference between failure and fragility could be interpreted as a matter of degree. But fragility is also used to describe the broad dynamics that would explain the state's deficiencies, notably dynamics related to economic growth, such as exclusion and inequality, and the guarantee of rights. This means that the difference between failure and fragility is also substantive, since the two reflect on distinct issues.

3 Olivier Nay's text (2013) is a bibliographical review of the literature critical to the concepts of 'failed states' and 'fragile states'. To specifically address the authors and texts systematised by Nay, we suggest that the reader access Nay's paper directly. The author mentions five 'families' of critics of the concept of fragile state. Apart from the critics already mentioned, the author also highlights 'the analytical reductionism' of the concept. These critics say that the concept is focused predominantly on an analysis of the state and the forces that cause an erosion of the same state. According to Nay, the authors of this group believe that studies on state fragility should focus on institutions outside the state perimeter. The last group of critics, less radical than the others, point out the lack of empirical studies that are dedicated to describing fragile states. According to these critics, the study of fragile states is usually superficial.

4 It is important to note that the aforementioned literature is critical and points out the limitations of the notion of fragile state. However, we believe that the criticism of the concept of fragile state and its consequent limitation to fieldwork are factors that help explain the emergence of the concept of a fragile city. According to the authors (Pureza et al 2005), state fragility would not necessarily be visible at the national level, but would be related to specific local contexts. A state that proves effective in a part of its territory could prove unable to provide public services in other regions; hence the importance of studying cities, or specific regions inside of cities.

5 Cities mentioned as case studies in Fractured Cities are: Rio de Janeiro, Mexico City, Medellin, Managua, Caracas, and Lima.

6 As in the case of the concept of a fragile state, the term 'fragile city', which was utilised earlier in the lexicon of aid organisations, later gained academic treatment. For a description of this process, see Nay (2013).

7 The term 'other situations of violence' appears repeatedly in Red Cross reports to refer to situations of violence not related to formally recognised conflicts or to the old wars. 'The International Committee of the Red Cross uses the term "other situations of violence" to refer to situations such as civil unrest, riots, state repression, violence in the aftermath of elections, gang violence and demonstrations. In these situations, the authorities often make extensive use of police or military force to maintain or restore law and order. While such situations do not reach the threshold of armed conflict, the humanitarian consequences can be as serious' (ICRC 2012). There is no legal definition of the term, which is used to justify the agency's operations, as well as that of other actors, in contexts of urban fragility.

8 Pureza (2012) states that within the ideological framework of the program defined as 'liberal peace', the new humanitarianism serves the cause of interventionism in turbulent peripheries, promoting Western values, forms of organisation, and rationality as responses to the root causes of local conflicts. The new humanitarianism would then serve to maintain the peripheries of the global system within a minimum of turbulence.

9 See endnote 2.

10 The initiatives mentioned here do not represent an exhaustive list. However, it seems to us sufficient evidence to demonstrate that urban fragility studies are potentially incorporated by aid agencies for the development of new humanitarian aid practices.

\section{References}

Active Learning Network for Accountability and Performance in Humanitarian Action (ALNAP). 2014. Annual Report 2013-14. ALNAP. At http://www.alnap.org/resource/19214. [Accessed on17 January 2017]. 
Beall, Jo, Tom Goodfellow and Dennis Rodgers. 2011. 'Cities, conflict and state fragility'. Crisis States Research Centre, Working Paper No. 85.2, London School of Economics and Political Science.

Call, Charles T. 2008. 'The fallacy of the "failed state". Third World Quarterly, 29(8): 1491-1507.

Carment, David, Stewart Prest and Yiagadeesen Samy. 2007. 'Assessing Fragility: Theory, Evidence and Policy'. Politorbis, 42: 13-19.

Cities and Fragile States. 2015. Cities and Fragile States Website. At http://www.lse.ac.uk/internationalDevelopment/research/crisisStates/Research/cafs.aspx [Accessed on17 January 2017].

Crisis States Research Centre (CSRC). 2006. 'Crisis, Fragile and Failed States: Definitions used by the CSRC.' Crisis States Workshop, London, March. At http://www.lse.ac.uk/internationalDevelopment/research/crisisStates/download/drc/Faile dState.pdf. [Accessed on 17 January 2017].

De Boer, John. 2015. 'Resilience and The Fragile City'. Stability: International Journal of Security and Development, 4(1), p.Art. 17. DOI: http://doi.org/10.5334/sta.fk. At http://www.stabilityjournal.org/ articles/10.5334/sta.fk/\#n7. [Accessed on 17 January 2017].

Department for International Development (DFID). 2005. Why we need to work more effectively in fragile states. London: DFID. At http://www.jica.go.jp/cdstudy/library/pdf/20071101_11.pdf. [Accessed on 17 January 2017].

Duffield, Mark. 2001. Global Governance and the new wars: the merging of development and security. London: Zed Books.

Duijsens, Raimond. 2010. 'Humanitarian challenges of urbanization'. International Review of the Red Cross, 92(878): 351-368. At https://www.icrc.org/eng/resources/international-review/review878-urban-violence/review-878-all.pdf. [Accessed on 17 January 2017].

Escamilla, Veridiana. 2015. 'Las 50 ciudades más violentas del mundo’. Forbes, 25 January. Online. At http://www.forbes.com.mx/las-50-ciudades-mas-violentas-del- mundo/. [Accessed on17 January 2017].

Fassin, Didier. 2012. Humanitarian Reason: A Moral History of the Present. Berkeley: University of California Press.

Graham, Stephen. 2009. 'The Urban Battlespace'. Theory Culture Society, 26: 278-288.

Grünewald, François, Béatrice Boyer, Domitille Kauffmann and Julie Patinet. 2011. Humanitarian aid in urban settings: current practice, future challenges. Plaisians: Groupe uRD, December. At http://www.alnap.org/pool/files/rapport-echo-urba-alnap-vfinale-aout.pdf. [Accessed on 17 January 2017].

Harrof-Tavel, Marion. 2012. 'Violence and humanitarian action in urban areas: new challenges, new approaches'. International Review of the Red Cross, 92(878): 329-350. At https://www.icrc.org/eng/ assets/files/other/irrc-878-harroff-tavel.pdf. [Accessed on 17 January 2017].

Instituto Igarapé. 2015. 'Homicide Monitor'. Instituto Igarapé. At http://homicide.igarape.org.br/. [Accessed on17 January 2017].

Inter-Agency Standing Committee (IASC). 2010. IASC Strategy: Meeting Humanitarian Challenges in Urban Areas. New York/Geneva: United Nations. At https://interagencystandingcommittee.org/ system/files/legacy_files/Final\%20Printable\%20IA SC\%20Urban\%20Humanitarian\%20Strategy. pdf. [Accessed on 17 January 2017]. 
International Committee of the Red Cross (ICRC). 2010. International Review of the Red Cross, 92(878), June. At https://www.icrc.org/eng/resources/international-review/review-878-urbanviolence/review-878-all.pdf. [Accessed on 22 May 2017].

2013. Urban Violence: What Role For Traditional Humanitarianism? 21 March. London:

ICRC At https://www.icrc.org/eng/assets/files/2013/urban-violence-summary-report.pdf. [Accessed on 17 January 2017].

IRIN. 2013. Urban violence - new territory for aid workers. 08 January. Online. At http://www.irinnews.org/report/97188/urban-violence-new-territory-for-aid-workers. [Accessed on 22 May 2017].

Kaldor, Mary. 2013. 'In Defence of New Wars'. Stability: International Journal of Security and Development, 2(1), p.Art. 4. DOI: http://doi.org/10.5334/sta.at.

Koonings, Kees and Dirk Kruijt. 2007. Fractured cities: Social exclusion, urban violence and contested spaces in Latin America. London: Zed Books.

Lucchi, Elena. 2014. Humanitarian Interventions in Situations of Urban Violence. ALNAP Lessons Paper. London: ALNAP/ODi. At http://www.alnap.org/pool/files/alnap- lessons-paper-urban-violence.pdf. [Accessed on17 January 2017].

Medecins Sans Frontieres (MSF). 2012. 'Facing an Epidemic of Urban Violence in Honduras'. Medecins Sans Frontieres [online], 25 October. At http://www.doctorswithoutborders.org/news-stories/ field-news/facing-epidemic-urban-violence-honduras. [Accessed on 17 January 2017].

Muggah, Robert. 2012. Researching the Urban Dilemma: Urbanization, Poverty and Violence. International Development Research Centre. At http://www.hasow.org/uploads/trabalhos/98/ doc/1401774567.pdf. [Accessed on 17 January 2017].

2013. 'The Fragile City Arrives'. E-International Relations, 23 November. At http://www.eir.info/2013/11/23/the-fragile-city-arrives/. [Accessed on 17 January 2017].

2014. 'Deconstructing the fragile city: exploring insecurity, violence and resilience'. Environment and Urbanization, 26(2): 345-358.

2015a. 'Fixing Fragile Cities: solutions for urban violence and poverty'. Foreign Affairs, 15, January. At https://www.foreignaffairs.com/articles/africa/2015-01-15/fixing-fragile-cities. [Accessed on 17 January 2017]

2015b. 'It is time for humanitarian agencies to work in fragile cities'. Humanitarian Practice Network, 16 April. At http://www.odihpn.org/the-humanitarian-space/news/announcements/ blog-articles/its-time- for-humanitarian-agencies-to-work-in-fragile-cities. [Accessed on 17 January 2017]

Muggah, Robert and Kevin Savage. 2012. 'Urban Violence and Humanitarian Action: Engaging the Fragile City'. The Journal of Humanitarian Assistance, 19 January. At http://sites.tufts.edu/jha/archives/1524. [Accessed on 17 January 2017]

Nay, Olivier. 2013. 'Fragile and failed States: Critical Perspectives on Conceptual Hybrids (Literature Review Essay)'. Paper prepared for the 22nd IPSA World Congress of Political Science, 8-12 July, 2012. At http://paperroom.ipsa.org/papers/paper_7560.pdf. [Accessed on 17 January 2017].

Nogueira, João Pontes. 2014. 'From Fragile States to Fragile Cities: Redefining Spaces of Humanitarian Practices'. HASOW Discussion Paper 12, October. At http://www.hasow.org/uploads/trabalhos/133/doc/837898282.pdf. [Accessed on 17 January 2017]. 
Norton, Richard J. 2003. 'Feral cities - The New Strategic Environment'. Naval War College Review, 56(4): 97-106.

Organisation for Economic Cooperation and Development (OECD). 2008. 'Concepts and dilemmas of State building in fragile situations: From fragility to resilience'. OECD Journal on Development 9(3): 61-148. At http://www.keepeek.com/Digital-Asset-Management/oecd/development/concepts-and-dilemmas-of-state-building-in-fragile-situations_journal_dev-v9-art27-en\#. WSZQlRPysWo\#page1. [Accessed on 17 January 2017].

Palus, Nancy. 2013. 'Humanitarian intervention in violence-hit slums - from whether to how'. IRIN, 15 May. At http://www.irinnews.org/report/98038/humanitarian-intervention-in-violence-hitslums-from- whether-to-how. [Accessed on 17 January 2017].

Patrick, Stewart. 2011. Weak Links: Fragile States, Global Threats, and International Security. Oxford: Oxford University Press.

Pureza, José Manuel. 2005. Prevenção de conflitos armados, cooperação para o desenvolvimento e integração justa no sistema internacional. Coimbra: Centro de Estudos Sociais. At http://www.ces. uc.pt/myces/UserFiles/livros/385_prevencao_conflitos1.pdf. [Accessed on 22 May 2017].

. 2012. “Doutrina do caos” que prevaleceu na Líbia ameaça Síria e Grécia, diz líder português'. Opera Mundi, 30 May. Interviewed by João Novaes. At http://operamundi.uol.com.br/conteu $\mathrm{do} /$ noticias $/ 22162 /$ doutrina + do+caos+que+prevaleceu+ na+libia+ameaca+siria+e+grecia+diz+lid er+portugues.shtml. [Accessed on 17 January 2017].

Putzel, James. 2010. 'Why Development Actors Need a Better Definition of "State Fragility"'. Policy Directions, September: 1-4. London School of Economics and Political Science, Crisis States Research Centre. At http://eprints.lse.ac.uk/41300/1/StateFragilityPD.pdf. [Accessed on 24 May 2017]. Putzel, James and Jonathan Di John. 2012. Meeting The Challenges Of Crisis States. London: Crisis States Research Centre, London School of Economics and Political Science. At http://www.lse.ac.uk/ internationalDevelopment/research/crisisStates/download/finalreport/M eeting-the-ChallengesExecutive-Summary.pdf. [Accessed on 17 January 2017].

Raleigh, Clionadh. 2015. 'Urban Violence Patterns Across African States'. International Studies Review, Volume 17(1), March: 90-106.

Rao, Vyjayanthi. 2006. 'Slum as theory: The South/Asian city and globalization'. International Journal of Urban and Regional Research, 30(1): 225-232.

Reid-Henry, Simon and Ole Jacob Sending. 2014. 'The "Humanitarization” of Urban Violence'. Environment \& Urbanization, 26(2): 427-442.

Roy, Ananya. 2016. 'Who's afraid of postcolonial theory?' International Journal of Urban and Regional Research, 40(1): 200-209.

Sassen, Saskia. 2010. 'When the City Itself Becomes a Technology of War.' Theory, Culture \& Society, 27(6): 33-50.

Solomon, Hussein. 2013. 'Discarding the Failed State Thesis: Neo-Weberian Institutionalism as an Alternative Approach to Policy Formulation'. Journal of Administrative Sciences, 11(22): 221-251.

Sorensen, Georg. 1999. 'Failed States and International Security II: Sources of Prevention, Modes of Response, and Conditions of State Success and Renewal. Paper delivered at the conference on Failed States and International Security II: Sources of Prevention, Modes of Response, and Conditions of State Success and Renewal, Pur- 
due University, West Lafayette, 8-11 April. At http://www.comm.ucsb.edu/faculty/mstohl/failed_ states/1999/papers/Sorensen.html. [Accessed on 22 May 2017].

Stepputat, Finn and Lars Engberg-Pedersen. (2008) 'Fragile States: Definitions, Measurements and Processes'. In Fragile Situtations: Background Papers. Copenhagen: Danish Institute for International Studies, pp. 21-31. At http://dcism.dk/graphics/Publications/Reports\%202008/R2008_11_Fragile_ States_\%20Definitions_Measurements_Processes.pdf. [Accessed on 17 January 2017].

Stewart, Frances and Graham Brown. 2009. Fragile States - CRISE WORKING PAPER No. 51, January. Oxford: CRISE. At http://r4d.dfid.gov.uk/PDF/Outputs/Inequality/wp51.pdf. [Accessed on 17 January 2017].

Suzin, Giovana. 2009. 'Cruz Vermelha em Favelas do Rio’. Observatório de Favelas, 29 October. At http://of.org.br/noticias-analises/cruz-vermelha-em-favelas-do-rio/. [Accessed on 17 January 2017].

Vainer, Carlos. 2014. 'Disseminating "best practice"? The coloniality of urban knowledge and city models' In Susan Parnell and Sophie Oldfield (eds), The Routledge handbook on cities of the Global South. New York: Routledge.

\section{About the authors}

Manoela Miklos holds an MA degree and a PhD degree in International Relations from the San Tiago Dantas Postgraduate Programme in International Relations (UNESP/ UNICAMP/PUC-SP), Brazil. Her doctoral thesis, defended in 2015, was entitled The urban dimension of contemporary conflicts and the fragile cities: new perspectives and practices. Her current research interests focus on the nexus between international and public security, gender issues, and cities as the locus of globalisation and of transnational phenomena. Currently, she works as Special Assistant for the Latin American Program at the Open Society Foundations, USA.

Tomaz Paoliello is Professor of International Relations at the Pontifical Catholic University of São Paulo (PUC-SP), Brazil. He holds an MA degree and a PhD degree in International Relations from the San Tiago Dantas Postgraduate Programme in International Relations (UNESP/UNICAMP/PUC-SP). His doctoral thesis, defended in 2016, was entitled The Anatomy of a Private Military and Security Company: DynCorp through a global perspective. He is also a member of the Research Group on International Conflicts (GECI/ PUC-SP). His current research focuses on private military and security companies, public-private security assemblages, the transnational dynamics of urban violence, and the contemporary logics of pacification and occupation. 


\section{Cidades Frágeis: uma Perspectiva Crítica sobre o Repertório de Novas Intervenções Humanitárias Urbanas}

Resumo: No final da década de 1990, pesquisadores envolvidos no debate sobre as novas guerras introduziram a discussão sobre a dimensão urbana dos conflitos contemporâneos na disciplina das Relações Internacionais. O debate inovador sobre a fragilidade urbana é uma das muitas linhas de pesquisa que emergem entre as análises sobre a relação entre cidades e conflitos contemporâneos. Este artigo procura demonstrar que o conceito de "cidade frágil" oferece um novo e relevante quadro analítico para a compreensão da violência e desigualdade urbana contemporânea. Argumenta-se que esse mesmo conceito pode, ainda, funcionar de maneira instrumental para tornar as cidades frágeis o novo local do humanitarismo internacional. A noção de cidade frágil emerge para descrever novas situações de emergência mais intimamente ligadas aos contextos urbanos do que à dinâmica nacional, conforme descrito anteriormente na literatura sobre estados frágeis. O conceito de cidade frágil é uma ferramenta inovadora para entender as conseqüências humanas da desigualdade em ambientes urbanos, mas também pode ser usado como um veículo retórico para a reprodução de dinâmicas antigas e para a inauguração de novas práticas de intervenção em áreas urbanas que anteriormente eram inacessíveis à ação humanitária, especialmente em cidades da América Latina.

Palavras-chave: Cidades Frágeis; Estados Frágeis; Ajuda Humanitária; Novas e Velhas Guerras; Novo Humanitarianismo.

Received on 31 August 2016 and approved for publication on 25 April 2017. https://creativecommons.org/licenses/by-nc/4.0/ 